Annals of Warsaw University of Life Sciences - SGGW

Land Reclamation No 47 (2), 2015: 127-137

(Ann. Warsaw Univ. Life Sci. - SGGW, Land Reclam. 47 (2), 2015)

\title{
Stabilization of bottom sediments from Rzeszowski Reservoir
}

\author{
KAROLINA KOŚ, EUGENIUSZ ZAWISZA \\ Department of Hydraulic Engineering and Geotechnics, University of Agriculture in Cracow
}

\begin{abstract}
Stabilization of bottom sediments from Rzeszowski Reservoir. The paper presents results of stabilization of bottom sediments from Rzeszowski Reservoir. Based on the geotechnical characteristics of the tested sediments it was stated they do not fulfill all the criteria set for soils in earth embankments. Therefore, an attempt to improve their parameters was made by using two additives - cement and lime. An unconfined compressive strength, shear strength, bearing ratio and $\mathrm{pH}$ reaction were determined on samples after different time of curing. Based on the carried out tests it was stated that the obtained values of unconfined compressive strength of sediments stabilized with cement were relatively low and they did not fulfill the requirements set by the Polish standard, which concerns materials in road engineering. In case of lime stabilization it was stated that the tested sediments with $6 \%$ addition of the additive can be used for the bottom layers of the improved road base.
\end{abstract}

Key words: bottom sediments, stabilization, cement, lime

\section{INTRODUCTION}

Siltation process, which occurs in dam reservoirs as a result of decreasing flow velocities and sedimentation of the river load carried by tributaries, in many cases leads to negative effects, like decrease in a retention volume. In case of significant problems with siltation one of the methods used to regain the lost volume is dredging. As a result there are large quantities of bottom sediments, which are usually treated as waste and put on a heap. However, from the geotechnical point of view they can be valuable materials for embankments, levees or sealing. Thus determining their geotechnical parameters and possible ways of usage is crucial.

Rzeszowski Reservoir was built in 1973 in order to ensure proper operation of water intakes for the city of Rzeszów and for recreation functions. Water reservoir, created by damming the Wisłok river, originally had a capacity of 1.8 million $\mathrm{m}^{3}$ and area of 68.2 ha (www. krakow.rzgw.gov.pl). Currently $60 \%$ of the capacity of the reservoir is filled with sediments and this number is growing. Therefore the reservoir no longer fulfills its functions. Lately there has been a discussion between the authorities, residents of Rzeszów and environmentalists on dredging. It is estimated that about 1.5 million $\mathrm{m}^{3}$ of sediments can be dredged from the reservoir (www.tvp. $\mathrm{pl} /$ rzeszow).

Materials dredged from reservoirs, rivers or ditches are usually fine grained with an increased organic matter content (Madeyski and Bednarz 2004, 
Gwóźdź 2007). Tested sediments from Rzeszowski Reservoir are also fine grained material, according to geotechnical standards classified as silt, which has low permeability, increased organic matter content and high compressibility (Table 1). At optimum water content and high compaction it had relatively high values of the angle of internal friction and cohesion. Silts should not be used as a construction material in earthworks, especially in road engineering. Based on the geotechnical characteristics of the tested sediments it can be stated they do not fulfill all the criteria set for soils in earth embankments. Therefore an at- tempt to improve their parameters was made so they would meet all requirements and be used for earthworks purposes. One of the most common method to do that is chemical stabilization, which in general is based on mixing of stabilization agent with natural soils in order to improve strength properties of stabilized soil (Sas and Głuchowski 2013). Two of the most common additives were chosen - Portland cement and hydrated lime. Such chemical additives are designed to combine with the soil to change the texture, increase strength and reduce swell characteristics (Sas et al. 2013).

TABLE 1. Geotechnical parameters of the bottom sediments averaged material (Koś and Zawisza 2014)

\begin{tabular}{|c|c|}
\hline Parameter & Value \\
\hline $\begin{array}{l}\text { Fraction content [\%]: } \\
\text { sand, Sa } 2-0,063 \mathrm{~mm} \\
\text { silt, } \mathrm{Si} 0.063-0.002 \mathrm{~mm} \\
\text { clay, } \mathrm{Cl}<0.002 \mathrm{~mm}\end{array}$ & $\begin{array}{c}8.5 \\
83.0 \\
8.5\end{array}$ \\
\hline Name acc. to PN-EN ISO 14688-2:2004 & $\mathrm{Si}$ (silt) \\
\hline Uniformity coefficient [-] & 13.3 \\
\hline Specific density $\left[\mathrm{t} \cdot \mathrm{m}^{-3}\right]$ & 2.53 \\
\hline Ignition loss [\%] & 4.67 \\
\hline Organic matter content [\%] & 3.33 \\
\hline Optimum water content [\%] & 24.8 \\
\hline Maximum dry density $\left[\mathrm{t} \cdot \mathrm{m}^{-3}\right]$ & 1.445 \\
\hline $\begin{array}{l}\text { Permeability coefficient }\left[\mathrm{m} \cdot \mathrm{s}^{-1}\right] \text { at } \\
I_{s}=0.90 \\
I_{s}=1.00\end{array}$ & $\begin{array}{l}1.05 \cdot 10^{-8} \\
1.12 \cdot 10^{-9}\end{array}$ \\
\hline Passive capillary $[\mathrm{cm}]$ & 137.1 \\
\hline Specific surface $\left[\mathrm{m}^{2} \cdot \mathrm{g}^{-1}\right]$ & 52.44 \\
\hline $\mathrm{pH}$ reaction $[-]$ & 7.30 \\
\hline Calcium carbonate content [\%] & 4.68 \\
\hline Liquid limit [\%] & 40.6 \\
\hline Plasticity limit [\%] & 26.8 \\
\hline Plasticity index [\%] & 13.8 \\
\hline Linear swelling [\%] & 26 \\
\hline
\end{tabular}




\section{MATERIAL AND METHODS}

Portland cement $32.5 \mathrm{R}$ and hydrated lime were used in 3, 6, 9 and $12 \%$ in relation to the dry mass of the sediments. An optimum water content and maximum dry density were determined in the Proctor apparatus for each mixture (the energy of compaction was $0.59 \mathrm{~J} \cdot \mathrm{cm}^{-3}$ ).

Unconfined compressive strength was determined on samples directly after compaction and after 7 and 28 days of curing (Table 2). The tests was carried out in a press where a plunger moved at the velocity of $10 \mathrm{~mm} \cdot \mathrm{min}^{-1}$. Samples in boxes that were $60 \times 60 \mathrm{~mm}$ in cross section. Samples that were $17.5 \mathrm{~mm}$ high, were formed at the optimum water content and compaction index $I_{S} \approx 1.0$. After 7 days of curing (as in UCS tests) samples were loaded with 50, 100, 150, 200 and $300 \mathrm{kPa}$ and then sheared until $10 \%$ of horizontal deformation was obtained. Strength parameters were calculated for the maximum values of shear stress $\left(\tau_{f \max }\right)$ using the method of least squares.

Bearing ratio $\mathrm{CBR}$ was also carried out on samples after 7 days of caring

TABLE 2. Samples curing before compressive strength tests

\begin{tabular}{|l|l|}
\hline Parameter & \multicolumn{1}{c|}{ Samples curing } \\
\hline UCS 0 & no curing, samples tested directly after compaction \\
\hline UCS 7 & $\begin{array}{l}3 \text { days in room temperature protected from drying, 1 day immersed in water up to } \\
10 \mathrm{~mm}, 3 \text { days immersed fully in water }\end{array}$ \\
\hline UCS 28 & $\begin{array}{l}13 \text { days in room temperature protected from drying, 1 day immersed in water up to } \\
10 \mathrm{~mm}, 14 \text { days immersed fully in water }\end{array}$ \\
\hline UCS 28 F/T & $\begin{array}{l}13 \text { days in room temperature protected from drying, 1 day immersed fully in wa- } \\
\text { ter, 14 freeze per a thaw cycles* }\end{array}$ \\
\hline
\end{tabular}

* One cycle is 8 hours of freezing in $-23^{\circ} \mathrm{C}$ and 16 hours of thawing in room temperature water; UCS 0 , UCS 7, UCS 28 - unconfined compressive strength of samples after $0,7,28$ days of curing; UCS $28 \mathrm{~F} / \mathrm{T}$ - unconfined compressive strength of samples after 28 days of curing with 14 freeze per a thaw cycles.

that were $80 \mathrm{~mm}$ in diameter and height were formed at optimum moisture content and compaction index of $I_{S} \approx 1.0$. Each test was repeated three times ( 3 samples for each mixture, altogether 94 samples). Compression strength was also determined for samples after 14 freeze per a thaw cycles (together 28 days) in order to calculate the frost resistance index.

Shear strength tests were carried out in standard direct shear box apparatus
(Table 2). Bearing ratio was determined using a plunger with $20 \mathrm{~cm}^{2}$ surface that penetrated the sample to 2.5 and $5.0 \mathrm{~mm}$ depth with constant velocity of $1.25 \mathrm{~mm} \cdot \mathrm{min}^{-1}$, the samples were loaded with $22.0 \mathrm{~N}$. During soaking with water (the last 4 days of caring) changes in samples height were measured in order to determine the linear swelling.

In order to determine the $\mathrm{pH}$ value $10 \mathrm{~g}$ of air dry samples were poured 
with $25 \mathrm{~cm}^{3}$ of distilled water and $25 \mathrm{~cm}^{3}$ of $\mathrm{KCl}$ solution at concentration of $1 \mathrm{~mole} \cdot \mathrm{dm}^{-3}$. After 24 hours electrodes were immersed into the sample and $\mathrm{pH}$ value was read from $\mathrm{pH}-$ meter scale.

\section{RESULTS}

\section{Cement stabilization}

The optimum moisture content of the sediments was over $25 \%$, the addition of $3 \%$ of cement caused its increase by $1 \%$ (Table 3). Further increase of cement

TABLE 3. Compaction parameters sediments with the addition of cement

\begin{tabular}{|c|c|c|}
\hline $\begin{array}{c}\text { Cement } \\
\text { addition } \\
{[\%]}\end{array}$ & $\begin{array}{c}\text { Maximum dry } \\
\text { density } \\
{\left[\mathrm{t} \cdot \mathrm{m}^{-3}\right]}\end{array}$ & $\begin{array}{c}\text { Optimum mois- } \\
\text { ture content } \\
{[\%]}\end{array}$ \\
\hline 0 & 1.445 & 24.80 \\
\hline 3 & 1.453 & 25.80 \\
\hline 6 & 1.434 & 25.50 \\
\hline 9 & 1.428 & 25.30 \\
\hline
\end{tabular}

addition did not cause any significant changes in the optimum water content. The maximum dry density of sediments was $1.44 \mathrm{t} \cdot \mathrm{m}^{-3}$. Along with the increase in cement addition up to $9 \%$ this value decreased to about $1.43 \mathrm{t} \cdot \mathrm{m}^{-3}$ (Fig. 1). As seen above the cement addition had little influence on the compaction parameters of the stabilized sediments.

Unconfined compressive strength of the stabilized sediments depended on curing time and cement addition (Table 4, Figs 2 and 3):

- samples tested directly after compaction had low strength, on average $0.16 \mathrm{MPa}$. The addition of cement caused increase of UCS up to $0.28 \mathrm{MPa}$ (for 6 and 9\% addition of cement);

- after 7 days of curing an increase in the values of UCS was noticed. At $3 \%$ addition it was $0.23 \mathrm{MPa}$, but with the increase of cement addition up to 6 and $9 \%$ an increase in UCS was

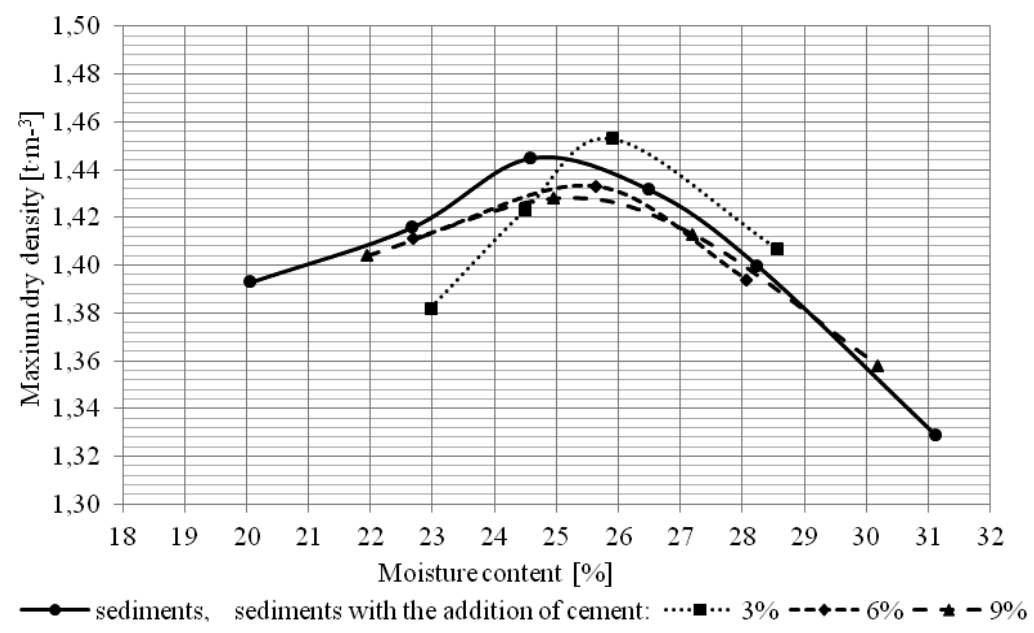

FIGURE 1. Relation between the dry density and the moisture content of sediments and their mixtures with cement 
TABLE 4. Parameters of sediments stabilized with cement in relation to the standard requirements (PN-S-96012:1997)

\begin{tabular}{|c|c|c|c|c|c|c|c|c|}
\hline \multirow{2}{*}{\multicolumn{2}{|c|}{ Parameter }} & \multicolumn{4}{|c|}{ Cement addition [\%] } & \multicolumn{3}{|c|}{ Requirements for } \\
\hline & & \multirow{2}{*}{$\begin{array}{c}0 \\
0.16\end{array}$} & \multirow{2}{*}{$\begin{array}{c}3 \\
0.26\end{array}$} & \multirow{2}{*}{$\begin{array}{c}6 \\
0.28\end{array}$} & \multirow{2}{*}{$\begin{array}{c}9 \\
0.28\end{array}$} & \multirow{2}{*}{$\frac{1}{-}$} & \multirow{2}{*}{$\begin{array}{l}2 \\
-\end{array}$} & \multirow{2}{*}{$\begin{array}{l}3 \\
-\end{array}$} \\
\hline \multirow{4}{*}{$\begin{array}{l}\text { Unconfined } \\
\text { compressive } \\
\text { strength [MPa] }\end{array}$} & $U C S_{0}$ & & & & & & & \\
\hline & $U C S_{7}$ & - & 0.23 & 0.45 & 0.62 & - & 1.0 & 1.6 \\
\hline & $U C S_{28}$ & - & 0.24 & 0.51 & 0.79 & 0.5 & 1.5 & 2.4 \\
\hline & $U C S_{28}^{\frac{\mathrm{F}}{\mathrm{T}}}$ & - & -* & 0.03 & 0.13 & - & - & - \\
\hline \multicolumn{2}{|c|}{$\begin{array}{l}\text { Frost resistance index } \\
n=\frac{U C S_{28}^{Z-0}}{U C S_{28}}\end{array}$} & - & - & 0.06 & 0.16 & 0.6 & 0.6 & 0.7 \\
\hline
\end{tabular}

* Samples fell apart gradually during the second cycle; 1 - lower parts of the improved ground under road embankment, 2 - top parts of the improved ground at least $10 \mathrm{~cm}$ thick under KR5-6 or top parts of the improved weak ground from frost heave soils, 3 - base for road under KR1 or subbase under KR2 to KR6 (KR - traffic category, 1 - light traffic, 6 - heavy traffic).

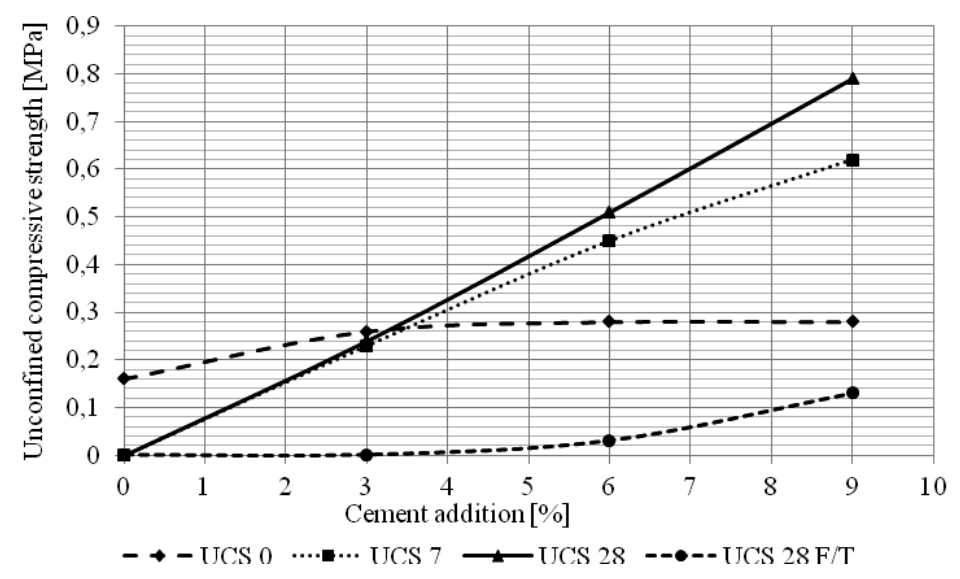

FIGURE 2. The influence of cement addition on the compressive strength of the stabilized sediments

obtained, 0.45 and $0.62 \mathrm{MPa}$ respectively (the values were 1.6- and 2.2times higher than in case of samples tested directly after compaction);

- after 28 days of curing a further increase of UCS was noticed for all samples - from 0.24 to 0.51 and $0.79 \mathrm{MPa}$, which is 1.0-, 1.1- and 1.3-times higher than in case of UCS values after 7 days of curing;

- after freeze and thaw cycles the samples had low strength - the samples with $3 \%$ addition of cement disintegrated just after two cycles, whereas 


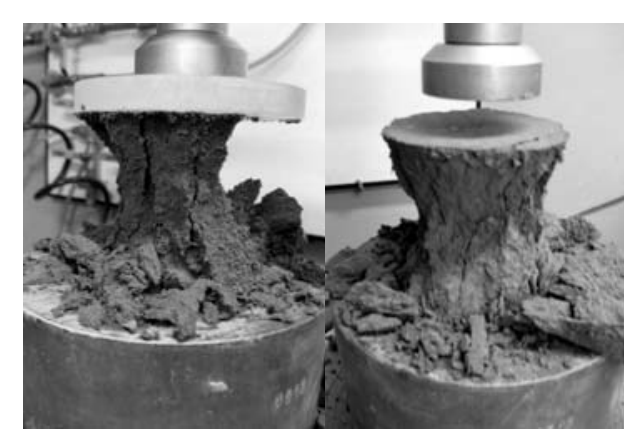

FIGURE 3. Samples failure during the unconfined compressive strength test (photo: author)

the UCS of the samples with the addition of 6 and $9 \%$ was only 0.03 and $0.13 \mathrm{MPa}$, with a weight loss of 80 and $40 \%$ respectively;

- frost resistance indexes were low and increased from 0.06 up to 0.16 along with the cement addition from 6 to $9 \%$.

While comparing the obtained results with the Polish standard requirements (PN-S-96012:1997) it can be stated that:

- sediments with 3 and $6 \%$ addition of cement do not fulfill the standards concerning the compressive strength and frost resistance and they cannot be used in road engineering;

- sediments with $9 \%$ addition of cement fulfill the requirements for lower layers of the improved ground under a road embankment concerning UCS, but because of a low value of frost resistance index they also cannot be used.

The values of shear strength parameters depended on the cement addition (Table 5). Angle of internal friction increased from $40^{\circ}$ up to over $45^{\circ}$, and
TABLE 5. Shear strength parameters of sediments stabilized with cement

\begin{tabular}{|l|c|c|c|}
\hline \multirow{2}{*}{ Parameter } & \multicolumn{3}{|c|}{ Cement addition [\%] } \\
\cline { 2 - 4 } & 3 & 6 & 9 \\
\hline $\begin{array}{l}\text { Angle of internal } \\
\text { friction }\left[{ }^{\circ}\right]\end{array}$ & 40.0 & 42.3 & 45.3 \\
\hline Cohesion $[\mathrm{kPa}]$ & 7.8 & 7.1 & 10.2 \\
\hline
\end{tabular}

cohesion from almost 8 up to $10 \mathrm{kPa}$, along with the increase in cement addition from 3 to $9 \%$. The obtained values of the angle of internal friction are much higher than the values for unstabilized sediments (for samples formed at the optimum water content and the compaction index $I_{s}=0.95$ which were soaked during shearing the angle was $24.3^{\circ}$ (Koś and Zawisza 2014). On the other hand, values of cohesion were low, which was probably the result of curing time - during the last 4 days the samples were soaked in water and the moisture content increased by about $25 \%$.

Cement stabilization improved geotechnical parameters of the bottom sediments - there was an increase of the unconfined compressive strength as well as shear strength and a slight increase of frost resistance. However, obtained values are too low and the tested material cannot be used in road engineering. Relatively low values of unconfined compressive strength are probably the result of increased organic matter content and lack of coarser fractions.

\section{Lime stabilization}

Based on Proctor tests similar shapes of compaction curves were obtained for samples with and without the lime ad- 
dition (Fig. 4). The addition of lime caused an increase of the optimum water content and decrease of maximum dry density. Optimum moisture content increased along with the addition of lime from about $25 \%$ for the sediments without any additive up to about $30 \%$ for samples with $12 \%$ addition of lime (Table 6). Maximum dry density of the sediments was $1.45 \mathrm{t} \cdot \mathrm{m}^{-3}$, whereas in case of mixtures with lime this parameter decreased to $1.34 \mathrm{t} \cdot \mathrm{m}^{-3}$.

Tested mixtures showed relatively low values of unconfined compressive strength, which were dependent on the curing time and lime addition (Table 7 , Fig. 5):

- after 7 days of curing the UCS increased from 0.17 to $0.26 \mathrm{MPa}$ along with the increase in lime addition from 3 to $9 \%$. Further increase in lime addition to $12 \%$ resulted in a lower value of compressive strength $-0.19 \mathrm{MPa}$;

- a longer curing time caused an increase of this parameter, which was from 0.22 to $0.35 \mathrm{MPa}$ respectively to the increase in lime addition from

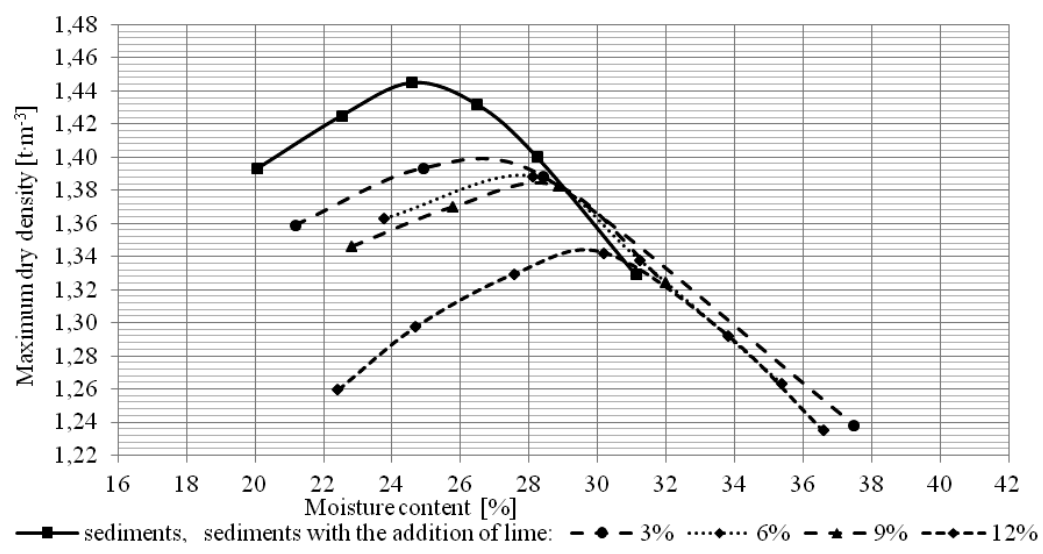

FIGURE 4. Relation between the dry density and the moisture content of sediments and their mixtures with lime

TABLE 6. Compaction parameters sediments with the addition of lime

\begin{tabular}{|c|c|c|}
\hline $\begin{array}{c}\text { Lime addition } \\
{[\%]}\end{array}$ & $\begin{array}{c}\text { Maximum dry } \\
\text { density } \\
{\left[\mathrm{t} \cdot \mathrm{m}^{-3}\right]}\end{array}$ & $\begin{array}{c}\text { Optimum } \\
\text { moisture } \\
\text { content } \\
{[\%]}\end{array}$ \\
\hline 0 & 1.445 & 24.80 \\
\hline 3 & 1.399 & 26.60 \\
\hline 6 & 1.390 & 27.70 \\
\hline 9 & 1.384 & 28.30 \\
\hline 12 & 1.343 & 29.60 \\
\hline
\end{tabular}

3 to $9 \%$. Similarly to UCS 7 samples with the $12 \%$ addition of lime had lower value $-0.22 \mathrm{MPa}$. These values were 1.3-times (for samples with 3, 6 and 9\%) or 1.1-times (for samples with $12 \%$ ) higher in relation to the ones tested after 7 days of curing; 
TABLE 7. Parameters of sediments stabilized with lime in relation to the standard requirements (PN-S-96011:1998)

\begin{tabular}{|c|c|c|c|c|c|c|c|c|c|}
\hline \multirow{2}{*}{\multicolumn{2}{|c|}{ Parameter }} & \multicolumn{5}{|c|}{ Lime addition [\%] } & \multicolumn{3}{|c|}{ Requirements for } \\
\hline & & 0 & 3 & 6 & 9 & 12 & 1 & 2 & 3 \\
\hline \multirow{3}{*}{$\begin{array}{c}\text { Unconfined } \\
\text { compressive } \\
\text { strength }[\mathrm{MPa}]\end{array}$} & $U C S_{7}$ & - & 0.17 & 0.21 & 0.26 & 0.19 & $\geq 0.3$ & $\geq 0.5$ & $\geq 0.2$ \\
\hline & $U C S_{28}$ & - & 0.22 & 0.27 & 0.35 & 0.22 & $\geq 0.4$ & $\geq 0.7$ & - \\
\hline & $U C S_{28}^{\frac{\mathrm{F}}{\mathrm{T}}}$ & - & \multicolumn{3}{|c|}{$-*$} & $-* *$ & $\geq 3 * * *$ & $\geq 5 * * *$ & - \\
\hline \multicolumn{2}{|c|}{$\begin{array}{c}\text { Bearing ratio } \\
\mathrm{CBR}_{7}[\%]\end{array}$} & 3.2 & 13.3 & 15.3 & 14.7 & 18.3 & $\geq 25$ & $\geq 40$ & $\geq 15$ \\
\hline \multicolumn{2}{|c|}{ Linear swelling [\%] } & 1.72 & 0.02 & 0.02 & 0.04 & 0.06 & $\leq 1.0$ & $\leq 0.5$ & $\leq 2.0$ \\
\hline \multicolumn{2}{|c|}{$\mathrm{pH}$ reaction [-] } & 7.30 & 12.07 & 12.49 & 12.49 & 12.58 & $\geq 7$ & $\geq 7$ & $\geq 7$ \\
\hline
\end{tabular}

* Samples fell apart gradually during the first cycle, ** samples fell apart gradually after the second cycle, *** number of freeze/thaw cycles; 1 - top layers of the improved ground - up to 1.0 under the road grade line, 2 - subbase for roads with light traffic, 3 - lower layers of the improved ground $1.0 \mathrm{~m}$ under the road grade line or initial improving of soils for further stabilization.

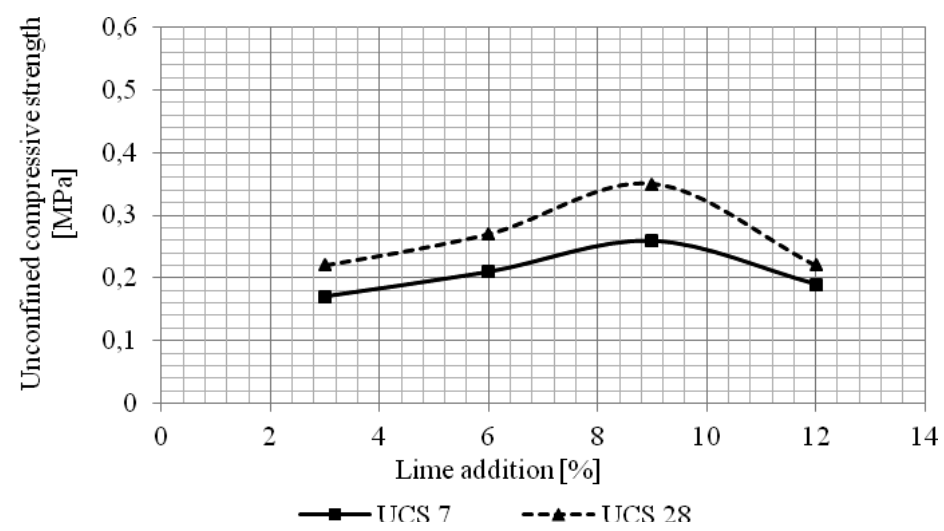

FIGURE 5. The influence of lime addition on the UCS of the stabilized sediments

- sediments stabilized with lime had low frost resistance - samples with 3, 6 and 9\% addition fell apart just after the first freeze per a thaw cycle and with $12 \%$ addition after the second cycle.

Shear strength parameters of sediments stabilized with lime were relative- ly high. A significant increase of strength was obtained in relation to the sediments without any additive. The angle of internal friction increased from over 35 to 38 along with the lime addition from 3 to $9 \%$ (Table 8 ). A similar relation was noticed by the authors (Gay and Schad 2000, Glinicka 2006), but in both cases 
TABLE 8. Shear strength parameters of sediments stabilized with lime

\begin{tabular}{|l|c|c|c|c|}
\hline \multirow{2}{*}{ Parameter } & \multicolumn{4}{|c|}{ Lime addition [\%] } \\
\cline { 2 - 5 } & 3 & 6 & 9 & 12 \\
\hline $\begin{array}{l}\text { Angle of internal } \\
\text { friction }\left[{ }^{\circ}\right]\end{array}$ & 35.3 & 37.0 & 37.7 & 29.8 \\
\hline Cohesion $[\mathrm{kPa}]$ & 6.1 & 6.7 & 6.5 & 18.9 \\
\hline
\end{tabular}

there was also a significant increase of cohesion, which was not noticed in case of the tested sediments. This parameter increased slightly along with the increase in lime addition and was over $6 \mathrm{kPa}$. Less favorable value of the angle of internal friction was obtained for sediments with $12 \%$ addition of lime, as it was in case of unconfined compressive strength. This proves that the percentage of lime for effective action is in the range of 5 to $10 \%$ (Purushothama Raj 2008).

A significant increase of bearing ratio was noticed as a result of lime stabilization (Table 7). CBR of the sediments without any additive was just over $3 \%$. It increased from over 13 to $18 \%$, along with the increase in lime addition from 3 to $12 \%$.

Linear swelling determined for the pure sediments was relatively high - over $1.7 \%$. The addition of lime had a significant influence on this parameter, it decreased to $0.02 \%$ (for samples with 3 and $6 \%$ addition) and $0.06 \%$ (for samples with $12 \%$ ).

The $\mathrm{pH}$ reaction of sediments was neutral -7.3 , the lime addition resulted in a much higher values, from 12.0 to 12.6.

Based on the analysis of the obtained results and the Polish standard require- ments (PN-S-96011:1998) it can be stated that:

- sediments with $3 \%$ addition of lime do not fulfill the standards and they cannot be used in road engineering;

- sediments with $6 \%$ addition fulfill all the requirements concerning compressive strength, bearing ratio as well as linear swelling, set for lower layers of the improved ground $(1.0 \mathrm{~m}$ under the road grade line) or for the initial improving of soils for further stabilization;

- sediments with 9 and $12 \%$ addition can also be preliminary allowed for lower layers of the improved ground or for the initial improving, they fulfill the requirements concerning compressive strength, bearing ratio and linear swelling, but in case of sediments with $9 \%$ addition the value of CBR is close to the required one $14.7 \%$ in relation to $15 \%$ and in case of sediments with $12 \%$ the value of UCS 7 is $0.19 \mathrm{MPa}$ in relation to the required $0.20 \mathrm{MPa}$.

The addition of lime resulted in a higher compressive strength, shear strength as well as bearing ratio and lower linear swelling. Additionally, because of drying properties of lime, which are crucial in case of soils with high moisture content, using this method of stabilization is worth considering.

\section{CONCLUSIONS}

Stabilization using cement improved geotechnical parameters of tested bottom sediments, an increase of unconfined 
compressive strength, shear strength and frost resistance was noticed. Although the addition of cement did not improve these parameters sufficiently and the stabilized sediments stabilized do not fulfill the requirements set for the soils in road engineering. Stabilized soils have a mixed structure, there are aggregates of load-bearing structure and fine soil grains of filling. Load-bearing structure is a result of binding processes between the stabilizer and dispersed silty and sandy fractions. Soil particles which are not bound with the stabilizer are the filling and binder for aggregates of the load-bearing structure and at the same time they are a kind of shock absorber that allows obtaining mixtures with high elasticity to external forces (Wiłun 2000, Pisarczyk 2004). Bottom sediments from Rzeszowski Reservoir consist mainly of silt and sand fractions so good results of their stabilizations with both cement and lime were expected. Although the results have shown that unconfined compressive strength was lower than expected. High organic matter content could have a great influence on stabilization process. In general $2 \%$ of organic matter content is the limit allowable value for soils stabilized with cement, though good results of stabilization with cement were obtained with soils that had even 3 to $4 \%$ of organic matter content and at the same time $0.5 \%$ greatly reduced bearing capacity of the soil (Wiłun 2000). Therefore the decisive measure of usability of soil in cement stabilization have to be the unconfined compressive strength test on stabilized soil samples.

Relatively favorable results were obtained by using lime as an additive. Its addition caused an increase of unconfined compressive strength, shear strength, bearing ratio and slight increase of frost resistance in relation to the sediments without the stabilizer. The recommended addition of lime is $6 \%$ - the mixture met all the criteria set for lower layers of the improved ground or for the initial improving of soils for further stabilization. It can be stated that the recommended method of stabilization in case of silty sediments with the addition of organic matter content is lime.

\section{Acknowledgments}

The results of research carried out under the theme DS-3322/KIWiG/2014 were financed with a grant for science conferred by The Ministry of Science and Higher Education.

\section{REFERENCES}

GAY G., SCHAD H. 2000: Influence of cement and lime additives on the compaction properties and shear parameters of fine grained soils. Otto-Graf-Journal 11, 19-31.

GLINICKA M.J. 2006: Właściwości geotechniczne gruntów spoistych z terenu Białegostoku wzmacnianych cementem lub wapnem [Geotechnical properties of cohesive soils from Białystok area improved by cement and lime]. Drogi i mosty 4, 23-39 [Engl. summ.]

GWÓŹDŹ R. 2007: Properties of cohesive sediments form Rożnowksie Lake in the aspect of their geotechnical usage. Doctoral dissertation. Politechnika Krakowska. Cracow. MS. 
KOŚ K., ZAWISZA E. 2014: Geotechnical characteristics of bottom sediments from Rzeszowski Reservoir. Journal of Civil Engineering, Environment and Architecture 3 (in press).

MADEYSKI M., BEDNARZ J. 2004: Wykorzystanie osadów dennych wybranego zbiornika wodnego [Usage of bottom sediments of a chosen water reservoir]. Zesz. Nauk. AR w Krakowie, Inżynieria Środowiska 25, 283-292 [Engl. summ.]

SAS W., GŁUCHOWSKI A. 2013: Effects of stabilization with cement on mechanical properties of cohesive soil - sandy-silty clay. Ann. Warsaw Univ. of Life Sci. - SGGW, Land Reclam. 45 (2), 193-205.

SAS W., GLUCHOWSKI A., MARGIELSKI J. 2013: Estimation of physical and mechanical properties of cohesive soil stabilized by hydratized lime addition. Ann. Warsaw Univ. of Life Sci. - SGGW, Land Reclam. 45 (2), 143-157.

PISARCZYK S. 2004: Grunty nasypowe. Właściwości geotechniczne i metody ich badania [Soils in embankments. Geotechnical parameters and methods of their testing]. Oficyna Wydawnicza Politechniki Warszawskiej, Warszawa.

PURUSHOTHAMA RAJ P. 2008: Soil Mechanics and Foundation Engineering. Dorling Kindersley.

PN-S-96012:1997: Roads. Base and ground improved with cement. PKN, Warszawa.

PN-S-96011:1998: Roads. Lime stabilization for road purposes. Polish standard. PKN, Warszawa.

WIŁUN Z. 2000: Zarys geotechniki [Geotechnics]. Wydawnictwo Komunikacji i Łączności, Warszawa.
Streszczenie: Stabilizacja osadów dennych Zbiornika Rzeszowskiego. W pracy przedstawiono wyniki badań stabilizacji osadów dennych Zbiornika Rzeszowskiego. W wyniku przeprowadzonej oceny przydatności do celów budownictwa ziemnego stwierdzono, że przedmiotowe osady nie spełniają większości kryteriów określonych dla materiałów do nasypów drogowych. Podjęto zatem próbę poprawy ich parametrów geotechnicznych przez zastosowanie dwóch dodatków - cementu oraz wapna. Przeprowadzono oznaczenie wytrzymałości na ściskanie (dla próbek po różnych okresach pielęgnacji), wytrzymałości na ścinanie oraz wskaźnika nośności i odczynu (dla próbek stabilizowanych wapnem). Na podstawie badań przeprowadzonych dla osadów stabilizowanych cementem stwierdzono, że uzyskane wartości wytrzymałości na ściskanie są stosunkowo małe i nie spełniają wymagań PN-S-96012:1997 dotyczącej materiałów stosowanych w budownictwie drogowym. W przypadku stabilizacji wapnem stwierdzono, że zgodnie w wymogami PN-S-96011:1998 badane osady denne z 6-procentowym dodatkiem wapna moga być zastosowane na dolne warstwy ulepszonego podłoża drogi lub jako wstępne ulepszenie gruntów do dalszej stabilizacji.

Stowa kluczowe: osady denne, stabilizacja, cement, wapno

\section{MS. received May 2015}

\section{Authors' address:}

Karolina Koś, Eugeniusz Zawisza Uniwersytet Rolniczy w Krakowie Wydział Inżynierii Środowiska i Geodezji al. Mickiewicza 24-28, 30-059 Kraków Poland e-mail: karolinasudyka@wp.pl kiwig@ur.krakow.pl 